\title{
Reflections on the uptake of climate change policies by local governments: facing the challenges of mitigation and adaptation
}

\author{
Thomas Hoppe*, Maya M van den Berg and Frans HJM Coenen
}

\begin{abstract}
Background: There is a growing body of literature that examines the role of local governments in addressing climate change vis-à-vis mitigation and adaptation. Although it appears that climate change mitigation strategies - in particular those addressing energy issues - are being adopted by a large majority of local governments, this cannot be said of climate change adaptation. This paper explores the uptake of these two types of climate change policy by local governments in the Netherlands. The central research question is: What lessons can be drawn from comparing the adoption and implementation of local climate change mitigation policies with local climate change adaptation policies in the Netherlands? Our paper contributes to the body of literature on climate change policy implementation, drawing particular attention to the ongoing debate on the institutional dimension of the adaptation-mitigation dichotomy.

Methods: A comparative case study research design was chosen to study the adoption and implementation of climate change (i) mitigation and (ii) adaptation policies by local governments in the Netherlands during the period 1998 to 2013. The data involved 89 expert interviews and secondary data sources from four research projects conducted by the present authors on local climate change policy implementation.

Results: Most Dutch municipalities have local climate change policies that address mitigation. Local governments pay relatively little attention to adaptation. The difference is mostly due to the take-up of central government-led policy support schemes aimed at the vertical integration of climate change mitigation policies. Moreover, mitigation is typically framed as an 'energy' issue whereas adaptation is framed as a 'water' issue. This has far-reaching consequences. Climate change adaptation has never been prioritized, nor has it been supported with properly funded policy support schemes.

Conclusions: In the realm of local climate change policies, adaptation is still considered an 'add-on' to climate change mitigation policy. Moreover, adoption and implementation of both adaptation and mitigation suffers from institutional inertia in Dutch local policy practice.
\end{abstract}

Keywords: Climate policy; Local governments; Climate change adaptation; Climate change mitigation; Cities

\section{Background}

An accumulating body of empirical evidence is revealing that climate change is becoming increasingly manifest [1]. Although climate change is perceived by many as a serious problem, the nature of the problem and its potential solutions in terms of policies remain the subject of sometimes fierce debate [2]. It is therefore fair to state

\footnotetext{
*Correspondence: t.hoppe@utwente.nl

Twente Centre for Studies in Technology and Sustainable Development (CSTM), University of Twente, P.O. Box 217, Enschede 7500 AE, The Netherlands
}

that climate change is a 'wicked' or ill-structured problem [3]. In response to climate change, governments throughout the world have framed problems and challenges - often in their own specific ways - and have proceeded to formulate their own climate change policies accordingly, in terms of goals, strategies, and means.

Local governments have an important role to play in society's response to climate change. In a broader sense, local governments have been named in many studies as a key actor in the transformation towards a more sustainable society [4-8]. Several arguments can be adduced

\section{实}


for focusing on the local level. First, of all tiers of government, it is the local level that has most contact with citizens and local businesses, which offers opportunities to act as an example and to facilitate local action. Second, there is a great deal of transformative potential, since many local decisions directly affect the environment, such as local authorities' regulation of local transportation, building construction, spatial planning, and economic matters.

Although local governments are paying increasing attention to climate change, their policies tend to concentrate most on climate change mitigation rather than climate change adaptation strategies when addressing the problems [9]. There are several reasons for this. First, climate change as frame of action to reduce human impacts on the environment has a long tradition. For a long time, mitigation formed the primary strategy for climate protection. Mitigation attempts to reduce the human impacts on the climate and includes major efforts on the global scale to achieve a reduction in greenhouse gas (GHG) emissions. This process has been institutionalized under the United Nations Framework Convention on Climate Change (UNFCCC), which coordinates the global negotiations on binding limits on greenhouse gases. Under the Kyoto Protocol, which became effective from 2005, a large majority of nations have committed themselves to limit or reduce annual emissions of greenhouse gases to 'reverse the effects of climate change' $[3,10]$. Second, climate change mitigation actions can easily be aligned to potential government strategies that focus on enhancing energy efficiency, renewable energy, or managing energy transition. Linking climate change action to energy policy action is attractive to many actors in the energy domain, including local governments and local communities.

From a climate change action perspective, however, a myopic focus on mitigation is unwarranted, as the argument first advanced in the mid-1980s has increasingly gained ground, that mitigation efforts would be insufficient to anticipate the human impacts on the global climate [11]. Due to the accumulation of greenhouse gases that have already been emitted, it is becoming increasingly apparent that climate change is inevitable. For this reason, society needs to prepare to cope with extreme weather events, and coordinated joint action is required. However, it is evident that reaching a collective crossnational mitigation strategy has proven to be very difficult. In contrast to climate change mitigation actions, for which negotiations at the supranational level are required, most climate change adaption actions can be taken at much lower aggregation levels [12], and especially at the local level. Hence, climate change action strategies should not only stress mitigation but also adequately address strategies targeting the impacts of climate change through adapting systems and societies, especially starting at the local level. Therefore, in contrast to the global efforts at mitigation, adaptation is being presented as a typical local issue [13]. Hence, it should follow from this reasoning that local governments would spend significant budgets, time, and effort to formulate and implement local climate change policies that pay sufficient attention to both mitigation and (in particular) adaptation.

National practices vis-à-vis local climate change policy, however, show differences in the uptake between adaptation and mitigation strategies. This study focuses on the Netherlands, a country which was for a long time considered a front-runner in (and exporter of) environmental policy, especially in the 1990s [14]. The country's climate change policy history goes back to the late 1980s when the Dutch government developed its first climate change policy actions based on the attention drawn to the climate change issue in the 1987 Brundtland report. The policies included programs for local governments to formulate and implement their own climate change action plans. Implementation seemed to proceed successfully: in 2010, a national survey found that local climate policies had been adopted by the vast majority of local governments throughout the country. However, this is a false impression, as revealed by further insights into the adaptation-mitigation distribution. Whereas climate change mitigation policies have indeed been widely adopted [15], the same cannot be said for the adoption of adaptation strategies, which varies strongly across municipalities in the country and is on average rather low [16]. This is surprising for a highly flood-prone country, with plenty of experience with extreme weather events and their horrendous impacts, like the 1953 North Sea flood, which killed hundreds of citizens.

In this paper we are interested in why the majority of climate change policies that have been implemented by local governments are predominantly formulated as climate change mitigation strategies and hardly ever as climate change adaptation strategies. In the academic literature, the overemphasis on mitigation and lack of attention to adaptation is referred to as the 'adaptationmitigation dichotomy' $[17,18]$. 'Historically, due to a wide variety of reasons, mitigation and adaptation have been framed by scientists and policymakers as two different approaches to deal with the same problem. As a result, there are large differences in the ways knowledge is produced, the analytical approaches that are used, and the designed policy strategies' ([17], p. 230). Proponents of adaptation on the one side and mitigation on the other have each been overemphasizing their own problem and suggested solutions, while disregarding the other side [17]. For instance, proponents of adaptive strategies were disregarded by proponents of mitigation 
strategies as 'defeatists', or 'fatalists', and their strategies were perceived as strategies 'to do nothing' [11,19]. Due to institutional path dependencies - that is, uncoordinated mainstreaming of adaptive and mitigative strategies in existing and new sectoral policies - the gap between the adaptation and mitigation discourses has widened even more [17].

Despite the presence of the adaptation-mitigation dichotomy, action can be undertaken to synergize adaptation and mitigation strategies, for instance by installing 'green roofs' on buildings or by taking other 'no-regret' measures [20]. It is hardly possible for local governments alone to implement such climate change synergy actions, however. It requires the involvement of local stakeholders (citizens, citizen associations and cooperatives, non-governmental organizations (NGOs), and local businesses) to realize these measures in practice. So, basically, given the amount of private property involved, city governments need to involve the private sector on many occasions [20].

The 'adaptation-mitigation dichotomy' debate is the stepping stone for our empirical analysis of how Dutch local governments have adopted and implemented mitigation and adaptation policies. In this paper we explore how mitigation became overemphasized in local climate change policy, whereas adaptation is still attracting insufficient attention. Our main research question is as follows:

What lessons can be drawn from comparing the adoption and implementation of local climate change mitigation policies with local climate change adaptation policies in the Netherlands?

We use a comparative longitudinal case study research design to compare the adoption and implementation of two policy domains by Dutch local governments: climate change mitigation and climate change adaptation. The paper comprises five sections. First, we discuss theoretical factors that explain the adoption and implementation of climate change policies by local governments. Second, we present a methods section. Third, we present the two cases of adoption and implementation of the two climate change policy domains by Dutch local governments. Fourth, we discuss the results of the comparative analysis. In the final section, we present our principal conclusions.

\section{Theoretical background: drivers of voluntary adoption of climate change policy by local governments}

There is a growing body of literature that examines the role of city governments in addressing climate change [9,21-25]. Part of this literature deals with attempts to explain the variation in what local governments do in respect of climate change.
To increase the intensity of efforts that local governments can make to implement earmarked policies (e.g., (supra)national mandates or national grants offered by central government), central governments can use intergovernmental policies. The use of such programs might offer a good explanation for differences between the level of efforts governments make in different nation states, as shown in the literature on the uptake of Local Agenda 21 [26]. If one views local government climate change mitigation policies as an implementation of the Kyoto goals, just as LA21 was of Agenda 21, it could be argued that the variation in climate change policy actions is closely (and positively) related to multilevel policy implementation ('vertical integration').

A policy implementation perspective presents classical success and failure factors, such as the capacity of the implementing local government, the availability of information, the beliefs held by the participants in the implementation process, and the power exercised by stakeholders. Evidence from empirical studies supports some of these claims. Most importantly, there is a strong relation between municipal size, availability of knowledge, degree of professionalization, and experience that civil servants have with the adoption and implementation of environmental policies (including climate change) [27]. Cities that meet these conditions are more likely to formulate and implement substantial local climate change policies. For example, large cities like Rotterdam in the Netherlands have a specialized department for climate policy, whereas small municipalities have to restrict themselves to the minimum requirements. For large municipalities (cities), this is not without reason, since they are more vulnerable to climate change-related impacts (e.g., 'urban heat stress').

In relation to this local capacity and climate change policy, Bulkeley and Betsill [21] list five preconditions that are related to the adoption of local climate change policies in the local political institutions, viz., (i) presence of a committed individual in a local-level government that (ii) manifests a solid climate protection policy (preventing GHG emissions), (iii) has funding available, (iv) has power over related domains, and (v) perhaps most crucially, has the political will to act. Furthermore, local capacity and climate policy actions are more prevalent when municipalities participate in transnational municipal networks [23,24]. One could argue that proponents of international pro-climate change networks advocate climate change actions that can be undertaken by local governments, which encourages public officials or civil servants from local governments to adopt them.

If one views local government commitment to implementing climate change policies as largely a voluntary effort, rather than an effort encouraged by national government through 'carrots' (economic government incentives) 
and 'sticks' (regulation; with mandatory compliance), this voluntary effort is explained in the literature by different sets of factors. Zahran et al. [28] use three contextual factors to explain local commitment to adopting and implementing climate change policy in their USbased study of International Council for Local Environmental Initiatives (ICLEI) membership of cities in metropolitan areas: (i) presence of climate change risk, (ii) presence of climate change stress, and (iii) presence of civic capacity ${ }^{\mathrm{a}}$. 'Climate change risk' addresses such factors as coastal proximity, ecosystem sensitivity, or proneness to flooding and other climate change-related risks. Ecological, social, and economic impacts are not distributed evenly geographically. Some local governments profit more from the reduction of climate change risks than others because they are more vulnerable to potential climate change impacts. But with climate change mitigation measures, the benefits cannot be excluded from other areas (and thus other municipalities) regardless of the effort local governments make to reduce GHG emissions. In the end it is municipalities that are the more vulnerable that benefit most. 'Climate change stress' relates to high levels of carbon-based employment, solo commuting with low urban density, and low levels of solar energy use, which means that from an economic perspective on transportation and energy use, climate change emission reduction becomes more costly for local communities. 'Civic capacity' is conceptualized as the presence of environmental groups and the involvement of environmental causes. Environmental groups can mobilize capacity and political support to raise attention to climate change-related issues and influence local policymakers' agenda setting. The involvement of environmental groups in agenda setting is of critical importance in the development of climate change policies [28]. Enhancing civic engagement (to empower environmental groups) is therefore considered a key challenge in cities [29].

According to Sharp et al. [30], the (contextual) factors mentioned by Zahran et al. [28] overlap with a few more general factors. However, Sharp et al. [30] claim that Zahran et al. [28] are wrong to omit the role of political institutions. Sharp et al. [30] add two more factors: (i) (types of) political institutions and (ii) the 'need-based' scope of the problem. The 'political institutions' explanation stipulates how the government of institutions matters with respect to particular earmarked local policies. This varies across polities. In the US context, there are different institutional arrangements of the city management model, whereas the Netherlands has just one mayor-council model, which is used by all 420 Dutch municipalities. The 'need-based' scope of the problem proposes that the uptake of sustainability policies is a function of the scope of the problem to which such policies are addressed, for instance to lower GHG emissions as an argument to lower energy use, or run local energy saving campaigns to raise employment numbers. In our opinion, the 'need-based' focus is an economic focus in a very strict sense: local government officials use climate change (mitigation) as a means to achieve financial-economic goals.

Table 1 summarizes the theoretical drivers for adoption and implementation of climate change policy by local governments.

\section{Methods}

This section addresses the research design, data collection, and data analysis of the study on which this paper is based.

\section{Research design}

A comparative case study research design was used. Case study research designs are used to study contemporary phenomena in real-life contexts [31]. The method affords a detailed understanding and comparison of social phenomena like public policies (e.g., in our case, local climate change policy). (Comparative) case study research designs are used for policy evaluation, and the method is accepted by most researchers in the field. We focused on the implementation of climate change policies by local governments in the Netherlands in the period 1998 to 2013. We compared two policy domains: climate change adaptation and climate change mitigation. Case selection comprised the

\section{Table 1 Theoretical drivers for adoption and implementation of climate change policy by local governments}

\begin{tabular}{ll}
\hline Category & Theoretical drivers \\
\hline $\begin{array}{l}\text { Policy incentive by } \\
\text { Local government } \\
\text { organization }\end{array}$ & Intergovernmental policy scheme \\
& Municipal size \\
& Availability of knowledge \\
& Degree of professionalization \\
& Participation in transnational \\
& 'pro-climate change' networks \\
& Presence of committed public \\
& official with political will to act \\
& Presence of committed \\
& and experiential civil servant(s) \\
& Power over related (policy) domains \\
Availability of (earmarked) funding \\
Climate risk \\
Climate stress \\
Civic capacity \\
Type of political institution \\
Fontitical institutions & policies as a 'need-based' issue \\
\hline
\end{tabular}


two leading climate change policy domains (adaptation and mitigation) that have a local impact. We omitted the third climate change policy type identified by IPCC (i.e., research on new technologies, institutional designs, and climate and impacts science), as we feel it is not relevant since it does not require adoption and implementation of climate change policies by local governments, but is mainly addressed at the national level.

\section{Data collection}

The data used were compiled from text documents and 89 in-depth interviews (32 on climate change adaptation [32] and 57 on climate change mitigation [33-35]). The interviewees are municipal climate change policy coordinators (civil servants), other persons involved with climate change policy at the local level, and central government climate change policy officers. The results presented here derive mostly from an NWO (The Netherlands Organisation for Scientific Research) project on climate change and the social sciences, called 'Vulnerability Adaptation Mitigation' (VAM). Furthermore, data used also stem from other (policy evaluation) studies, notably that of Coenen and Menkveld [33].

\section{Data analysis}

The comparative analysis between local climate change mitigation policy and local climate change adaptation policy involved comparing information on seven policy indicators: (i) policy goals, (ii) main policy instruments used, (iii) the role of municipalities as implementing government agents, (iv) the degree of coordinated integration with existing policies and practices, (v) the degree of policy implementation, (vi) theoretical factors related to policy adoption by local governments, and (vii) future prospects. We operationalized the seven policy indicators as follows:

- Policy goals: Public policies are politically deliberated plans [36,37]. Policy goals are designed by policymakers, i.e., politicians and administrators. In order to achieve these goals, public policies (as strategic plans) are made and implemented.

- (Main) Set of policy instruments: a set of policy instruments used by government as strategic incentives to change the behavior of a given target group (in terms of direct or indirect behavioral change), either citizens or organizations [38]. Policy instruments can be sub-divided into three categories: information sharing (e.g., information campaigns), economic incentives (e.g., subsidy schemes, tax levies), and regulations [39]. Following interactive policy developments in the late 1990s, another type of policy instruments came into more widespread use: multilateral agreements (e.g., covenants) [40]. Our analysis addresses both policy instruments used by local governments themselves and policy instruments used by central government to encourage local governments to adopt climate change policies.

- The role of municipalities as policy implementation government agents: In this study the role of local governments should be seen as policy implementation agents [41]. Local governments implement climate change policies that strive to influence local target groups and organizations. The roles played by local governments in implementing public policies vary.

- The degree of policy implementation: Intended policy goals are not always met by implementation of policies that have been designed to attain them. When implemented in daily practice, problems occur related to lack of coordination and goal uniformity. In environmental policy (cf. climate change policy), lack of policy integration is seen as a major obstacle to goal attainment [42]. Due to political decision making, path dependency, and institutional inertia, domain-specific policies differ from one another.

- Theoretical drivers for the adoption and implementation of climate change policies by local governments: see Table 1 for an overview of the key theoretical drivers mentioned in the literature.

- Future prospects: Prospective signals and ideas on how a policy domain is likely to develop in the next few years (roughly 2013 to 2020) for the two policy domains addressed here.

\section{Results}

Case study I: adoption and implementation of climate change mitigation policies by local governments

In the Netherlands, climate change mitigation is framed by national government as a reduction of $\mathrm{CO}_{2}$ equivalent emissions. Climate change mitigation has been on the policy agenda in the Netherlands since 1988 following the Brundtland report [43]. Formally, however, 'climate change policy' has only been implemented following the Policy Note on implementation of climate change policy in 1998 ('Uitvoeringsnota klimaatbeleid') [44]. Nonetheless, policies indirectly aimed at the reduction of greenhouse gas (GHG) emissions, typically targeting energy saving, energy efficiency, or renewable energy, have been in place since the 1970s [37]. Following the Brundtland report and its translation in Dutch policy (the first national environmental plan), central government tried to encourage local governments to adopt local action plans that can be termed measures to ameliorate GHG emissions. However, this was a piecemeal approach as it was part of broader LA21 policy packages, using intergovernmental policy support schemes (e.g., VOGM [15,45]). Following the 1997 Kyoto 
Protocol, the public's attention to the reduction of GHGs in society rose dramatically. This was manifested both in increased national policy making and local initiatives, the latter greatly encouraged by environmental NGOs (e.g., Milieufederaties, COS'en).

\section{National policy for adoption of climate change mitigation policies by local governments}

In 1998 the Netherlands translated the Kyoto Protocol approach into its own national climate change policy action plan, laid down in the 'Uitvoeringsnota klimaatbeleid 1998' [44]. Although the policy plan is called a 'climate (change) policy implementation plan', the focus is on mitigation of GHG emissions, not climate change adaptation. In fact, the minister framed the plan according to the advice by the VROM-raad (Ministry of Housing, Spatial Policy and the Environment (HSPE) Council) on the 'transition to a low energy economy' [46].

The HSPE was responsible for the implementation of climate policy. Responsibilities for policy implementation were differentiated across multiple central government ministries (in line with the several sectoral policy domains in which climate policy is actually implemented, such as transport, the built environment, and the energy sector) and to the central government agency 'SenterNovem' - then part of the Ministry of Economic Affairs $[47,48]$. For 'outsiders' this comprehensive sharing was not entirely clear and created confusion [47]. A key element of the policy plan involved the contribution of economic sectors and multiple levels of government to achieve the national $\mathrm{CO}_{2}$ equivalent emission reduction targets. The plan included an administrative scheme designed to encourage local governments to adopt climate policies. By that time, 'climate change policy' was predominantly perceived as 'climate change mitigation policy.' Furthermore, multilateral agreements were signed with industrial and business partners to meet climate change mitigation goals in various economic sectors.

Local governments were also to be involved in the national climate change action plan. To national government, the challenge was to encourage local authorities to develop their own local climate change policies and have them implemented. Because Dutch local governments enjoy autonomous decision-making powers, central government could not impose the adoption of predefined top-down climate policy upon them. Rather, they had to deploy intergovernmental subsidy schemes that would fund less than half the costs local governments were to incur for the development and implementation of local climate change policy.

From 1999 local governments could apply for the grants under the first of two local climate change policy schemes ('Bestuursakkoord Nieuwe Stijl', abbreviated as 'BANS'). The more ambitious the climate change policy proposed by local governments in their action plans, the larger the subsidy granted by central government. The BANS scheme was designed to create substantial local capacity, because most local governments were often ill prepared, except for the few that had been active in preparing climate policy measures during the 1990s, following the LA21 policy support scheme. The BANS scheme allowed local climate change policy to be designed in various sectoral policy fields in which local governments exercise an influence: (i) design and codification of local climate policy in implementation plans, (ii) $\mathrm{CO}_{2}$ reduction in municipal buildings, (iii) $\mathrm{CO}_{2}$ reduction in housing (owned by house owners), (iv) $\mathrm{CO}_{2}$ reduction in office buildings (owned by local companies), (v) $\mathrm{CO}_{2}$ reduction by rural entrepreneurs, and (vi) $\mathrm{CO}_{2}$ reduction in transport and mobility [49]. It should be clear from the presentation of these policy schemes that local governments alone cannot effectively implement climate change mitigation measures in the local society, because they depend heavily on compliance by local actors to achieve their climate change mitigation goals (cf. [48]).

\section{Local climate change mitigation policy developments}

Implementation of local climate policy stimulation schemes can roughly be divided into a start-up phase (1999 to 2006) in which local climate policy plans were developed, and a perpetuation phase (2007 to present) in which local capacity becomes continuous and policy is actually implemented.

From 1999 to 2006, the BANS scheme encouraged local governments to develop local climate change policies, by providing budgetary means, information (on examples of policy packages and measures that could typically be taken, see the following list), and tailor-made advice. Except for a few large municipalities already active in the domain of climate change mitigation or energy efficiency, climate change was not considered a priority by local communities. Often it was individual municipal officers with 'pro-climate change' attitudes who pushed for their municipalities to participate in the BANS scheme on local climate change policy adoption [50]. Besides the BANS scheme, grants from other policy sectors were available (e.g., on renewable energy and energy efficiency) for exploratory studies on the development of 'energy visions', and (spatial) planning by determining $\mathrm{CO}_{2}$ reduction potentials of future projects (e.g., development of residential areas). Local governments hired consultants to carry out these studies [51]. Many of the resulting reports became 'blueprints' for the development of local climate policies. Strikingly, these policies were subject to hardly any critical ex ante feasibility analysis [34]. As a consequence, and in part due to strategic agenda setting by public officials, many 'energy visions' and local climate policies were formulated in overly 
ambitious terms, paying little attention to the local context. In fact, local stakeholders were often not even invited to participate in the policy-making processes [51]. In summary, local climate policy making had become a technocratic top-down affair, with little scope for the exercise of democratic control by local political representatives [49].

An overview of typical climate change mitigation policy measures used by Dutch municipalities [52] is as follows:

(a) The municipality strives to have an up-to-date climate policy program and assigns high priority to it.

(b) The municipality has the ambition to achieve being a carbon neutral municipality within the next few years.

(c) $\mathrm{CO}_{2}$ monitoring: the municipality annually calculates its $\mathrm{CO}_{2}$ production (by both citizens, business firms and your own municipal organization).

(d)There is a structural earmarked financial budget in the municipality for climate change policy.

(e) The municipality uses the SLOK (intergovernmental) policy scheme to encourage local climate policy.

(f) The municipality employs a civil servant tasked with energy conservation and renewable energy.

(g) The municipality communicates climate change to its populace, with the aim of raising public support for its local climate policy. In practice, this means at least one information activity annually, aimed at the public at large.

(h)The municipality implements a policy program aimed at schools and other education institutes.

(i) The municipality actively encourages energy conservation among its inhabitants and home owners.

(j) The municipality sets measurable targets for the share of energy that derives from renewable sources (solar, wind, biomass, hydropower, geothermal heating, and cooling).

(k) The municipality supports active and structured collaboration with local stakeholders in the field of climate mitigation and/or energy policy.

(l) The municipality has a membership of the Klimaatverbond (Climate Alliance).

Organizationally, taking up local climate change policies meant that municipalities had to develop a new mode in which coordination and collaboration between the traditional sectoral policy departments in municipalities was to be arranged. In practice, (large-scale) municipalities appointed 'climate coordinators' (often with no dedicated administrative budgets) or environmental officers to manage and coordinate the policy planning and implementation. By the end of the BANS scheme period, more than half of the Dutch municipalities (237 in total; 12 provinces) were participating in the policy scheme and were on their way to developing their own local action plans [53].

Worldwide attention to climate change grew (again) in 2006. This affected the policy agendas of both central and local governments. Local governments, organized in 'VNG' (the Dutch municipalities' federation), initiated the 'Climate Agreement' [54], which called both for close intermunicipal collaboration on climate change issues and with central government. The agreement was generally well received by municipalities throughout the country. For municipalities it now became a 'policy fashion' to design their own climate change mitigation policies. The new national government coalition, which involved a new environmental minister, Prof. Jacqueline Cramer, adopted the initiative in its new national climate policy, which provided a new local climate policy support scheme (for Local Climate Change Initiatives, abbreviated as 'SLOK'). The scheme was designed to achieve the perpetuation of local climate change policy capacity and implementation of policy plans (in collaboration with local stakeholders) developed under the BANS scheme. Not surprisingly, the SLOK scheme, like its predecessor, used the 'menu card' approach for municipalities to (quasi-)tailor their local climate change mitigation strategy [55]. The scheme provided local governments with financial support to hire personnel, conduct research, educate staff, and develop a communication strategy [56]. Furthermore, local climate mitigation policies were assisted by support policies from other sectoral policy domains, in particular renewable energy (by the introduction of a new support scheme called 'New Energy for Climate' [57], which enabled local actors to apply for subsidy grants for investments in innovative renewable energy (technical) appliances). These and other schemes enabled local governments to play a role as 'launching customer' to create market demand for renewable energy [58]. This created demand in the local energy value chain, which facilitated local energy (decentral) producers to start producing (assuming demand to follow the supply of energy).

By 2011, local climate change policies had been formulated by the majority of municipalities. A study showed that $95 \%$ of municipalities had succeeded in formulating their own climate change policy (mitigation) plans. Furthermore, the 2010 local authority elections showed that climate change policy had become a political issue which was reflected in most local political parties' election manifestos [59]. Moreover, nearly $82 \%$ of municipalities had applied for SLOK scheme grants, $87 \%$ of municipalities looked for opportunities for renewable energy production in spatial zoning plans, and 59\% of municipalities stated 
they were involved in actively engaging local stakeholders to become producers of renewable energy [60]. Furthermore, among environmental policy programs, climate change (mitigation) policy had become the most frequently used option. Looking at policy output, a study by Hoppe and Coenen [15] revealed that the use of available policy instruments had increased substantially from $47 \%$ in 2007 to $65 \%$ in 2009. The best equipped municipalities, however, were large in size, particularly those that were already the forerunners during the 1990s. At a stroke, it can be seen that local climate change mitigation policy had become commonplace among Dutch municipalities.

In many cases the municipalities also feature 'green' motivated and committed public officials, members of the Green-Leftist Party, and equipped with sufficient committed staff members, who would remain in post for years. Often these staff members had a background in and memberships of environmental NGOs. The uptake and implementation of local climate policy was to a significant extent related to this so-called personal factor, since uptake and policy making relied heavily on the political will and power of a few to act.

Although policy output on climate mitigation looks quite substantial, this can hardly be said of the persistence of established local capacity and policy implementation, as local capacity remains dependent on intergovernmental funding. This is illustrated by the fact that since the termination of the SLOK scheme in 2011, two thirds of all municipalities participating in the Climate Treaty have cut the number of projects concerned with local climate policy [61]. The upward trend from 2008 to 2011 was therefore disrupted [62]. This view was highlighted in a nationwide survey held in 2013, as nearly half of the municipalities stated that they were not going to meet their local climate change policy targets [60].

With regard to policy implementation, significant problems already applied in the SLOK era and will likely not be solved or alleviated in the absence of a national support scheme. In part these problems are related to the complex institutional organization of climate mitigation policy in the Netherlands. ${ }^{\text {b }}$ It is no longer clear what the (quantified) $\mathrm{CO}_{2}$ equivalent reduction goals are, who is responsible for meeting those goals, and who should act in practice to help achieve them. Moreover, it seems that many municipalities and other decentral governments are running their own climate change mitigation policies, and there is no official body that measures their performance on policy output and outcome indicators nor coordinates their activities [47]. The Netherlands Environmental Assessment Agency attributes these problems to a large extent to short-term policy views held by recent government coalitions and the neglect of implementing policies designed to have an impact on the long term [14].

This lack of goal orientation and policy organization is manifest in implementation problems at the local level, notably non-compliance by local stakeholders, lack of alignment with sectoral policies and the departments responsible for their implementation (following lack of policy integration), institutional barriers, cost overruns in local projects, lack of policy performance measurement, evaluation, and enforcement (e.g., $[37,58,63])$. Many of these problems arguably result from poor policy design, overambitious goal setting, and lack of stakeholder engagement and participation in the policy-making process $[34,51,58]$.

\section{What lies ahead?}

Although the picture sketched above looks rather gloomy, there is room for optimism. Since 2007, climate change mitigation issues, especially in the field of distributed generation of renewable energy, have attracted increasing attention from local communities and NGOs. This is shown by the rapid nationwide growth of local energy cooperatives, increasing by more than 300 since the first one was founded in 2007 [64]. Local energy cooperatives indicate the adoption of climate mitigation initiatives by citizens and 'grassroots movements.' Whereas the policy push factor for local climate mitigation policy seems to be in decline, civil society is taking responsibility into its own hands and seems to be seizing control of the gap the Dutch central government created by prematurely terminating the climate change mitigation policy support schemes. The Netherlands Environmental Assessment Agency concludes that: 'whereas it was national government that had to make citizens and business companies aware in the 1990's, currently it is quite the opposite: citizens and businesses are trying to make government aware. Furthermore, local governments take 'pro-active' action, and are not going to wait passively to comply with orders from central government' [14]. So it could very well be that the future of local climate change mitigation action lies with civil society, their energy cooperatives, and accompanying local business partners. In this vision local governments will retreat to a supportive, facilitating role. In fact, a few municipalities have already started experimenting with this new facilitating role, most notably the pioneering municipality of Lochem, led by alderman - and environmental front-runner - Thijs de la Court, whose policy redesign, practice, and experiences have attracted national attention [35]. Nonetheless, if civil society is to achieve climate change mitigation goals autonomously, it is not going to happen without substantial support from (central) government by removing institutional and legal barriers [65]. 


\section{Case study II: adoption and implementation of climate change adaptation policies by local governments}

In the Netherlands, climate change adaptation has long been associated with preventing flooding. This is no surprise since half of the country's territory is flood prone and is therefore considered to be one of the most vulnerable countries of the European Union by the European Environmental Agency [66]. Moreover, having 'conquered' much of its territory from the sea, the Dutch have a strong tradition of post-event adaptation to flooding. When dykes were breached, they were rebuilt and strengthened. After the 1953 North Sea flood - which killed 1,850 people - the general mood was that this should never happen again. It resulted in the realization of an extensive water engineering program, closing off river mouths and sea arms and enforcing drastic norms of up to one flooding even per 10,000 years. Behind their safe dykes, the Dutch 'forgot' their vulnerable location [67]. Only in the mid1990s - when the major rivers in 1993 and 1995 had to discharge unusual quantities of rain and melt water from the Alps, causing huge financial and physical damage 'water' once again rose up the agenda. In this setting, water-based adaptation was taken on board as part of a national shift towards a more integrated water management that commenced in 2000 [68]. Other (non-waterbased) climate change adaptation strategies were less formalized by central government, or not embraced at all.

\section{National adaptation policy}

As compared to other European Union (EU) Member States, climate change adaptation strategies are considered to rank high on the national political agenda, and many motivational and facilitating factors are in place [18]. However, it was not until 2007 that a National Adaptation Strategy (NAS) was developed that approached climate change adaptation from a more holistic perspective [69]. The program was set up to enable national, provincial, and municipal government representatives, together with representatives from water boards and experts, to regularly discuss the multilevel dimension of adaptation issues [18].

NAS was inspired by a senate motion calling for explicitly taking climate change into account in investment decisions and for a long-term vision of the future development of the Netherlands [70]. This was part of a program that included NAS, a national adaptation agenda, and a research track in which, among others, the degree of climate change resilience of the Netherlands was examined (termed the Adaptation, Space and Climate program, abbreviated as 'ARK' program). The research track was later succeeded by two research programs. A broad range of ministries were involved in the development and implementation of the ARK program (Ministries VROM, V\&W, LNV, and EZ) as well as the umbrella organizations representing the Dutch decentralized governments. In the ARK program, all sectors affected by (potential) climate change impacts were considered in the strategy that identified safety, climate, biodiversity, and economy as the main themes for adaptation. Focusing on spatial adaptation, NAS referred to non-spatial measures - e.g., public health - being considered in other policy processes. Furthermore, large research budgets were made available by governments and public organizations for regional and local vulnerability and adaptation research projects [18]. The actions mentioned were planned to materialize in the form of a national adaptation agenda, but this was never delivered.

Parallel to the ARK program process, an advisory committee was established to advise on sustainable coastal development (the 'Sustainable Coastal Development' commission, which is generally known as the Delta Commission). It advised on the realization of a Delta Act and a Delta Commissioner who should be made responsible for a Delta program, which should make the country 'climate proof.' The Delta Commissioner commenced work in 2010, and the Delta Act was enacted in 2012. The ARK program was terminated in 2010, and its goals were adopted by the Delta Program. However, the broad approach that was applied in NAS was reframed in the Delta Program to water safety and freshwater supply, a reduction in terms of topics and actions vis-à-vis climate change adaptation.

The termination of the ARK program meant a break in the trend of Dutch climate change adaptation policy. When NAS disappeared, it was not succeeded by a similar program. As a consequence the Netherlands was left without a national, overarching climate change adaptation program with concrete measures for all sectors for which adaptation to climate change is basically required. The Delta Program is a national program, but focuses primarily on water safety and freshwater supply and climateresilient urban development - it does not consider all sectors that are vulnerable to climate change, including public health [71]. Therefore, the Dutch Court of Audit concluded in its report on the national policy on climate change adaptation that "successive governments in recent years have taken steps to adapt to the changing climate, but the current policy is fragmented and does not cover all areas that are vulnerable to climate change. Therefore, a risk exists that the country is insufficiently prepared for the consequences of climate change" (present authors' own translation) [71].

Through its general association, the local level has been drawn into national policy on adaptation as one of the partners to the NAS trajectory. In addition, a 
national-local agreement was effective from 2007 to 2011 in which the local government committed to national ambitions on climate change policy, which was mostly concerned with climate change mitigation efforts, but also included a few climate change adaptation goals. Currently, the Delta Program is seen as the most important national program on climate change adaptation. One of its sub-programs, 'New Construction and Restructuring, aims at enhancing the level of local climate change adaptation. Under this program, a manifesto is being prepared that explains how to implement strategies for creating 'climate-proof' cities.

In addition to this, some pioneering cities have been developing their own initiatives, striving to become 'climate change proof' in the coming decades. An example is the country's fifth largest city, Eindhoven, which is striving to become 'climate change proof' by restoring its old network of creeks. However, compared to large cities like Eindhoven, small- and medium-sized towns are less active when it comes to the adoption of climate change adaptation policies. Here it is suggested that a lack of capacity in terms of (financial) means and staff members prevents local governments from adopting adaptation programs more broadly [72]. Furthermore, implementation of climate change adaptation policies at the local level is hampered by institutional inertia. Climate change adaptation problems like flooding and urban heat stress are 're-framed' to problems in established policy domains in which public officers feel they are knowledgeable and experienced. Therefore, it comes as little surprise that 're-framing' of new policy issues like climate change adaptation actions (and problems) towards established 'policy silos' forms a substantial barrier to implementation of climate change adaptation policy at the local level [73]. And like its climate change policy counterpart 'mitigation', local governments cannot prepare for the challenge of climate change alone and are dependent on the willingness of local - private sector - partners to coordinate operational climate change adaptation actions [74].

\section{Developments in local climate change adaptation policies}

Most of the local climate change adaptation action plans focus on perceived weather variability, which is typically narrowed down to increasing precipitation. Broader or more abstract projections of future weather and climate conditions are rarely taken into account. Municipalities' attention to increased precipitation and related flooding risk is not very surprising since municipalities are responsible for rain and sewage water management, which includes managing flooding rivers in their territory. An overview of operational climate change adaptation actions that local governments can implement is presented in the following list.
An overview of climate change adaptation policy measures applied by Dutch municipalities [75] is as follows:

(a) Water challenge

1. Aboveground drainage (e.g., open gutters, ditches)

2. Buffering and infiltration (e.g., porous paving, green roofs, water squares)

3. Decentralized treatment (e.g., helophyte filters)

4. Use of 'other' water (e.g., using precipitation in homes, use of groundwater)

5. Flood risk management (e.g., floating or amphibious buildings, raised constructions, temporary flood protection)

6. Desiccation (e.g., reduced paved surfaces, disconnection and seasonal retention, temporary rainwater buffers, deep water retention)

(b)Heat challenge (e.g., green roofs, shade provided by vegetation, green squares)

(c) Urban agriculture (e.g., community gardens, 'public' grounds)

(d)Air quality (e.g., urban ventilation, minimizing the amount of paved surface)

Indeed, most actions mentioned are those related to water challenges. Dutch municipalities pay much less attention to other risks related to climate change. For instance, only a few front-runner cities are taking action to address urban heat stress, and they have encountered considerable problems in stimulating the adoption of urban heat stress mitigation measures in local practice [73]. In summary, attention to climate change adaptation in Dutch municipalities generally comes down to anticipating current and projected shifts in precipitation patterns, which is now standard local water policy [16].

Climate change adaptation further seems to become 'absorbed' in local climate change programs, where it is increasingly seen as an expansion of existing climate change mitigation strategies. Furthermore, climate change adaptation plans can be characterized as monosectoral rather than cross-sectoral. This observation is also valid when one looks at traditional policy domains capturing and 're-framing' measures to mitigate urban heat stress problems. Currently, heat stress hardly seems to be perceived as an urgent problem, mainly because there is no clear 'problem owner' [73]. It seems as if like the current generation of adaptation strategies does not consider the necessary cross-linkages in order to create efficiency and deploy the joint potential of knowledge, expertise, and skills to cope with climate change. In common with Runhaar et al. [73] and Uittenbroek et al. [74], we judge that there is an absence of efforts to enhance policy integration and mainstreaming of measures to adapt to climate change. 


\section{Current capacity}

Dutch municipalities depend quite heavily on central government funding. However, the Dutch adaptation strategy described above argued that an appropriate setting should be created at the local level by encouraging social learning, self-organization, and mobilization within the given legislative, financial, and technological frameworks [18]. The majority of local governments are, however, barely responsive. Even in cities located in flood-prone areas, policymakers adopt a 'wait and see' stance, waiting until earmarked, central governmentinitiated schemes allow them financially to implement local climate adaptation policy actions. Strikingly, indepth case study research has shown that even municipalities at increased risk of climate change-induced flooding did not turn out to be of much importance in formulating local climate change adaptation policies [16]. Therefore, local financial leeway to take up voluntary tasks, such as climate change policy actions in a broad sense, can be characterized as limited. In response to the EU Green Paper on climate change adaptation, the Association of Dutch Municipalities stated that 'the regional and local governments are seen as the level where much should be done on adaptation, while they do not or rarely receive additional funding to really tackle the problems' $[4,76]$.

To some extent, related to this, central government is generally seen by the local level as 'owning' the problems that are 'produced' by climate change. Hence, central government is expected to prioritize climate change adaptation as a general policy issue and then coordinate and facilitate the local implementation process. While climate change mitigation was promoted in the 1990s and the 2000s through funding schemes, this is not the case for climate change adaptation. As a result, adaptation policies are rarely coordinated locally, nor are there any strong incentives to develop more coherent local climate change adaptation programs [72]. Nonetheless, it has been observed more recently that increasing climate change adaptation activity is being witnessed in cities (in common with other Western countries) [77]. However, there are only a few pioneers in the Netherlands, but they do have the intention to disseminate their best practices. In this they have not yet succeeded, as they have not reached a responsive audience; the vast majority of medium-sized municipalities show little advance in formulating local adaptation strategies. This may be related to a variety of factors: poor problem recognition, a lack of political priority due to the presence of (traditional policy domain) problems that are considered more urgent, expectations that flood risk will be lower than expected or not occur at all, and a lack of incentives in terms of regulations and economic incentives [73]. Most actions related to climate change adaptation by local governments still concentrate around the water domain (flooding risk), with much less local institutional capacity to deal with other climate change adaptation domains. Moreover, climate change synergy measures like constructing 'green roofs' and other 'no-regret options' will likely only be adopted when they not only serve climate change adaptation purposes but integrate them into (other) established policy domains and deliver broader societal benefits [20,74].

\section{What lies ahead?}

In 2012, the General Audit Office concluded that there is limited consistency in Dutch climate change adaptation policy at the national level. In response to this, the responsible Secretary of State explained that a 'Climate Change Roadmap' is now being prepared in which a broad, coherent vision of both climate change mitigation and adaptation is envisioned [78]. This offers the possibility to reach a cross-sectoral approach to adaptation in which not only water but also disaster management, public health, and the environment are integrated. This is even more likely as the now dominant adaptation program - the Delta Program - will end in 2014. This will probably give room to a different approach to adaptation. Perhaps then too other sectors that will be also affected by climate change can be addressed, as well as the interfaces between the affected sectors. Shifts can also be observed at a local level. The idea of the 'climate active city' is now spreading. This calls for more attention to adaptation in conjunction with mitigation.

\section{Discussion}

Table 2 presents the main results from the comparative analysis on the adoption and implementation of climate change policies by Dutch local governments.

Our conclusion with regard to the uptake of climate change mitigation and adaptation policies and the linkage between these two pathways is that climate change mitigation - in particular due to its framing towards energy saving and renewable energy - is considered a very popular topic that appeals to citizens and local government public officials, and a substantial number of their civil servants (but certainly not all of them). The uptake of mitigation policies at the local level since the late 1990s has shown a steadily increasing trend, although it has been declining of late (following the 2011 termination of the SLOK scheme). Multilevel policy (vertical) support schemes were instrumental to this effort. In large part due to these schemes, the 2000 to 2010 decade can be characterized as a relatively top-down policy affair. Although local capacity for climate change mitigation policy actions has increased substantially in this period, little is known about actual goal attainment. However, it is difficult to argue that this also holds for 
Table 2 Results of the comparative analysis on the taken up local climate change mitigation and adaptation strategies

\begin{tabular}{ll}
\hline Climate change mitigation \\
\hline Policy goals & Local climate change mitigation policy goals in terms of \\
& $\mathrm{CO}_{2}$ equivalent reduction vary between municipalities \\
& (e.g., striving to become 'climate neutral' in 2030 or \\
& attain a $50 \% \mathrm{CO}_{2}$ emission reduction by 2020). Policy \\
& goals are often framed as 'energy' goals (e.g., achieve \\
& improved energy efficiency of $30 \%$ by 2020 or achieve a \\
& $50 \%$ share of renewable energy in the total local energy \\
& consumption by 2020) \\
& Local climate change mitigation policies should \\
contribute to the national government's climate change \\
policy goals, e.g., $\mathrm{CO}_{2}$ equivalent emission reduction of \\
6\% by 2010 (below the 1990 level)
\end{tabular}

Main set of policy instruments used

The role of municipalities as implementing governmental agents

Coordination and integration with existing policies and practices

Degree of implementation?

Factors positively related to climate change policy adoption by local governments.

\section{Climate change adaptation}

Varies between municipalities. Often involves flooding prevention (either from severe precipitation or rivers). A few cities have also stressed 'climate-proof' neighborhoods and urban heat stress and formulated policy goals accordingly

Coherent climate change mitigation support programs for vertical policy integration (at most $50 \%$ financed by national government; BANS, SLOK) were implemented by central government. Furthermore, there were support schemes in fields related to CC mitigation, such as awareness raising on energy saving and adoption of energy efficiency and renewable energy technologies (especially in the built environment)

Municipalities are the key local policy implementation actors. They may serve as 'best practice' for local communities and 'launching customer' for sustainable energy services. Furthermore, they have an intermediary role between central government and local communities and depend on the latter for commitment and compliance with local action plans. They are 'initiators' and 'local firebrands' for ' $\mathrm{CO}_{2}$ reduction activities' in local communities. They are network and process managers in local ' $\mathrm{CO}_{2}$ reduction projects' (in collaboration with local stakeholders)

Moderate. Municipalities have been adjusting their policies to some extent to allow for coordinated local ' $\mathrm{CO}_{2}$ reduction projects.' However, there is a great deal of institutional inertia which can only be changed when regulations are formally amended

High. By $2011,95 \%$ of municipalities had formulated their own climate change mitigation policy action plans, and climate change mitigation had become a topic in local politics with most parties having adopted it in their local election manifestos

Vertical policy integration support schemes (BANS, and later SLOK)
Several central government programs were implemented to stress CC adaptation, such as the NAS, the ARK program, the Delta Program, and research change-proof society

Although these programs focused on multileve governmental collaboration, they do not resemble support policy schemes comparable to BANS and SLOK, which were used for vertical policy integration in the CC mitigation domain

Local CC adaptation actions focused on water policy i.e., flood prevention, but hardly on other CC adaptation domains like urban heat stress

There was limited consistency in national CC adaptation policy strategies. Succession of national CC programs was problematic

Besides the water boards, municipalities are key implementing agents for climate change adaptation policy. They have an intermediary role between central government and local communities. They have some influence in infrastructural projects but depend strongly on compliance from other stakeholders, especially water boards, 'Rijkswaterstaat' (central government's waterways authority), citizens, and local businesses

Poor. Implementation of climate change adaptation policy faces many institutional barriers, both in the water domain (when dealing with flooding risks) and in the built environment (e.g., when dealing with urban heat stress). Flood prevention belongs to the water policy domain (and is hence dominated by water sector agencies, such as water boards, provincial governments, and 'Rijkswaterstaat')

Low. Climate change adaptation is not considered an important policy issue by municipalities (for lack of urgency and incentives). Flood prevention has been receiving moderate attention by a few flood-prone cities. Urban heat stress is still considered a non-issue. There are a few proactive front-runner cities in the country, though

Climate change adaptation actions are often only adopted when the objectives provide other broader societal benefit, in particular objectives that can be integrated with objectives in established policy domains

Size of municipal organization. A few (front-runner) cities have shown responsiveness to national programs like NAS. program for institutional designs of climate 


\section{Table 2 Results of the comparative analysis on the taken up local climate change mitigation and adaptation strategies} (Continued)

\begin{tabular}{|c|c|c|}
\hline & \multicolumn{2}{|l|}{$\begin{array}{l}\text { High degree of media attention to CC in 2006, and the } \\
\text { following inter-municipal deliberation that lead to the } \\
\text { signing of the National Climate Agreement in } 2007\end{array}$} \\
\hline & \multicolumn{2}{|l|}{$\begin{array}{l}\text { Presence of a highly motivated, influential, hardworking, } \\
\text { 'pro-climate change'-oriented municipal officer }\end{array}$} \\
\hline & \multicolumn{2}{|l|}{ Presence of a (pro-active) Green-Leftist public official } \\
\hline & \multicolumn{2}{|l|}{ Size of municipal organization [15] } \\
\hline & \multicolumn{2}{|l|}{$\begin{array}{l}\text { Membership of (international) } \\
\text { 'pro-climate change' NGO [15] }\end{array}$} \\
\hline $\begin{array}{l}\text { What lies ahead } \\
\text { (future prospects)? }\end{array}$ & $\begin{array}{l}\text { Local CC mitigation policy plans and 'local capacity' have } \\
\text { been established. The central government support } \\
\text { schemes were terminated (in } 2005 \text { and later in 2011), } \\
\text { though. In the near future, local governments will likely } \\
\text { have a supporting role and facilitate the increasing } \\
\text { number of civil society and business initiatives towards } \\
\text { adoption of local sustainable energy (efficient) systems } \\
\text { and hence reduce local GHG emissions }\end{array}$ & $\begin{array}{l}\text { A 'Climate Change Roadmap' is being prepared, which } \\
\text { includes a more coordinated vision and activities with the } \\
\text { climate change mitigation domain. There will likely be } \\
\text { more attention to cities broadening climate change } \\
\text { strategies from 'mitigation only' to 'mitigation + } \\
\text { adaptation'. This will be a challenge to most municipalities }\end{array}$ \\
\hline
\end{tabular}

CC, climate change; NAS, National Adaptation Strategy.

the engagement of local stakeholders and their compliance with local government action plans. After 2010, local citizens started to take matters more into their own hands, wanting to create their own 'low carbon,' 'climate neutral', or 'energy neutral' communities, with a desire for little government interference. At the same time, municipalities are confronted with decreased budgetary support from central government and the termination of the large-scale multilevel policy support schemes from the decade 2001 to 2011 . The future outlook is that local governments are retreating towards a supportive role $v i s-\grave{a}$-vis public service delivery in general and climate change mitigation policy in particular. Some frontrunner local governments are already running pilot projects to get used to this new role.

The climate change adaptation pathway is subject to reductionist framing towards an anticipation of severe precipitation and is institutionally embedded in water policy. Other seriously harmful issues, urban heat stress in particular, are barely addressed by local governments. Although there is some awareness of the scope and magnitude of risks related to climate change, it appears that the issue is not considered very urgent. This is indicated by the low degree of local capacity that has been created. Whereas climate change mitigation policy from the beginning had national priority and was followed up with additional financial support, this was not the case for climate adaptation policy. It seems that adaptation is framed to be just an 'add on' to climate change mitigation policy. As in other countries, the focus of local climate policy is mitigation, with a sectoral focus on the built environment and the transport sector [20]. Adaptation remains a neglected issue.

Next, we were interested in identifying drivers for the uptake of climate change mitigation and adaptation strategies by local governments in the Netherlands. The main factor is vertical policy-oriented support schemes, induced by national government, as shown in the climate change mitigation policy domain case. As observed in the empirical sections (of the two case studies), Dutch national government exercises a great degree of control by running vertical policy support schemes. Except for a few large cities that were pioneers in environmental policy well before the implementation of the vertical climate policy schemes, municipalities were to a large extent persuaded by central government. They were made aware of climate change policy action program alternatives, they were enabled to use central governmentdesigned local climate policy blueprints and 'models', and they were given a financial incentive to design and implement those policies. In the Netherlands, the BANS and SLOK schemes exerted a great positive influence on the uptake of local climate change mitigation policies. Arguably, the absence of such schemes has led to a lower uptake of adaptation policies at the local level. As studies in other countries have shown [27,79], central government-induced policy support schemes are vital to the vertical integration of climate policy. For the climate change mitigation line, the 2011 termination of the SLOK policy support scheme led to a discontinuance of progressive local climate change policy making, showing local governments that relying too much on central government support is not without risks due to increased dependence.

The climate change mitigation case provided evidence for claims addressing the positive influence of municipal size and factors related to the urgency of capacity building (availability of knowledge, degree of professionalization, experience held by civil servants, and participation in 'pro-climate change'-oriented municipal networks [21,24,27]). 
Furthermore, there seems to be evidence to support the 'committed individual' claim [21,29]. However, we do not consider this 'hard evidence' since further quantitative analysis is needed to test these claims more thoroughly.

We did not find any evidence of influence by the contextual factors 'climate risk' and 'climate stress' [28]. Strikingly, climate risk led to the formulation and implementation of hardly any climate change adaptation actions by local governments. For the contextual factor 'civic capacity', evidence was found that it actually takes 'ownership' of the climate change action plan away from local governments as citizens tend to take matters into their own hands (especially after 2011, when the SLOK scheme was abolished). So civic capacity seems to matter, but in a rather surprising way. Finally - and hardly surprisingly there is some evidence that climate change policies are framed as 'need-based' issues [30], in particular framed as a means to lower energy consumption costs (for both municipalities themselves and local residents, especially the poor), in the case of climate change mitigation policy.

This paper started with the outset of the adaptationmitigation dichotomy debate $[17,18]$. From the ways the two cases have evolved, we draw the following lessons. First, indeed, Dutch local climate change policy has been dominated by the climate change mitigation frame. This has to do with awareness, institutional inertia, and the association local communities have with climate change as an 'energy' issue. Moreover, in local climate change policy, there seem to be two discourses that have served to frame the adaptation and mitigation discourses: (a) the 'energy' discourse, shared with local civil society and energy policy domain stakeholders (climate change mitigation), and (b) the 'water' discourse, shared with water sector stakeholders. Since most municipal activities, however, draw upon local communities, and thus civil society, and their environment (the 'built environment'), it is not surprising that local governments overemphasize mitigation over adaptation, and 'energy' over 'water.' This also has to do with formal competences municipalities have, which are strongly rooted in established policy domains and tend to support the mitigation frame. Hence, besides central government-induced vertical policy integration policies, it is the system of formal rules and institutions that seem to 'lock in' local governments' climate change policy actions into a 'mitigation' paradigm that tends to neglect the other side of climate change: adaptation. Even climate adaptation issues that are more favorably sited in traditional municipal institutional regimes, like urban heat stress, attract surprisingly little attention from municipal officers. We argue that without significant support policies, and institutional 're-framing' of the meaning of local climate change, little change can be expected in the future from the perspective of a local government's taking action in the domain of climate change adaptation policy.

\section{Conclusions}

The central research question in this paper is: What lessons can be drawn from comparing adoption and implementation of local climate change mitigation policies with local climate change adaptation policies in the Netherlands? Our analysis shows that most Dutch municipalities have local climate change policies that address mostly mitigation. Attention to adaptation by local governments is still rather weak, which is strange for a country that is highly flood prone and increasingly vulnerable to the risk of urban heat stress. Five years after Biesbroek et al. [17] mentioned the adaptation-mitigation dichotomy, we note a still sizable difference between the adoption of the two policies by local governments. We believe that the difference in adoption rates between the two is mostly due to the use of central government-led policy support schemes aimed at vertical policy integration of climate change mitigation policies. Furthermore, mitigation is typically framed as an 'energy' issue whereas adaptation is (incorrectly) framed as only a 'water' issue. This has had far-reaching institutional consequences. Climate change adaptation was never really prioritized nor supported with properly financed policy support schemes to build capacity among local governments. In the realm of local climate change policies, adaptation is still considered an 'add on' to climate change mitigation policy. When looking at local policy implementation and the actual engagement of local stakeholders, however, both the adaptation and mitigation policies seem to suffer from institutional inertia in Dutch local policy practice, as local action is often only possible if concrete measures fit established policies, in particular in regard to permit granting (e.g., building permits). Furthermore, compliance by local stakeholders with local government climate change policy strategies remains troublesome. For mitigation, it is local stakeholders who seem to be enthusiastic to develop their own autonomous (sustainable energy) initiatives, and expect local government to become less dominant and to take a more passive, but supportive, stance. One might wonder whether such a role for local governments would be desirable in light of increasing extreme weather events and increasing attention to climate change adaptation. Should this be left to the market, considering that local governments in the Netherlands have shown themselves to be hardly bothered by it?

\section{Endnotes}

${ }^{a}$ ICLEI membership gives access to information, tools, and assistance for local governments to develop and implement climate mitigation policies.

${ }^{\mathrm{b}}$ In 2011, the already comprehensive organization of Dutch climate change mitigation policy went into organizational transition as the former Ministry of HSPE 
was split up and its former directorates general were integrated in the Ministry of Infrastructure and the Environment (IE) and the Ministry of Internal Affairs and Kingdom Affairs (IAKA). Agencies responsible for the implementation of climate change policy remained part of the Ministry of the Economic Affairs. This dispersion of responsibilities created further complexity in the organization of national climate change mitigation policy.

\section{Competing interests}

The authors declare that they have no competing interests.

\section{Authors' contributions}

All authors collected and analyzed the data. All authors were involved in drafting the manuscript. MB drafted the section on the case study vis-à-vis climate change adaptation. All authors read and approved the final manuscript.

\section{Received: 4 September 2013 Accepted: 13 March 2014} Published: 24 April 2014

\section{References}

1. IPCC (2007) Climate change 2007: synthesis report. Intergovernmental Panel on Climate Change, Geneva

2. Pielke R, Jr (2010) The climate fix: what scientists and politicians won't tell you about global warming. Basic Books, New York

3. Hoppe R (2008) Lost in translation? Boundary work in making climate change governable. In: Driessen P, Leroy P, Van Vierssen P (ed) From climate change to social change: perspectives on science-policy interaction. International Books, Utrecht, pp 109-130

4. Aall C, Norland I (2005) Indicators for local-scale climate vulnerability assessments. No. 65:1-130. Oslo. Program for Research and Documentation for a Sustainable Society (ProSus). ProSus, Oslo

5. Granberg M, Elander I (2007) Local governance and climate change: reflections on the Swedish experience. Local Environ Int J Justice Sustainability 12(5):537-548

6. Lindseth $G$ (2003) Addressing climate adaptation and mitigation at the local and regional level: lessons for Norway. ProSus, University of Oslo, Oslo

7. Storbjörk S (2007) Governing climate adaptation in the local arena: challenges of risk management and planning in Sweden. Local Environ Int J Justice Sustainability 12(5):457-469

8. Wilson E (2006) Adapting to climate change at the local level: the spatial planning response. Local Environ 11:609-625

9. Bulkeley $\mathrm{H}$ (2010) Cities and the governing of climate change. Annu Rev Environ Resour 35:229-253

10. United Nations (1998) Kyoto Protocol to the United Nations Framework Convention on Climate Change. UNFCCC. http://unfccc.int/resource/docs/ convkp/kpeng.pdf. Accessed 21 Mar 2014

11. Schipper $\mathrm{E}$ (2006) Conceptual history of adaptation in the UNFCCC process Rev Eur Community Int Environ Law 15(1):82-92

12. Klein R, Huq S, Denton F, Downing T, Richels R, Robinson J, Toth F (2007) Inter-relationships between adaptation and mitigation. In: Parry M, Canzian O, Palutikof J, Van der Linden P, Hanson C (ed) Climate change 2007: impacts, adaptation and vulnerability. Contribution of Working Group II to the fourth assessment report of the intergovernmental panel on climate change. Cambridge University Press, Cambridge, pp 745-777

13. VROM-raad (2007) De hype voorbij: Klimaatverandering als structureel ruimtelijk vraagstuk. VROM-raad, The Hague

14. Hoogervost N, Hajer M, Dietz F, Timmerhuis J, Kruitwagen S (2013) Wissels omzetten. Bouwstenen voor een robuust milieubeleid voor de $21^{\text {ste }}$ eeuw. Planbureau voor de Leefomgeving. Uitgeverij PBL, Bilthoven

15. Hoppe T, Coenen F (2011) Creating an analytical framework for local sustainability performance: a Dutch case study. Local Environ 16(3):229-250

16. Van den Berg $M$, Coenen $F$ (2012) Integrating climate change adaptation into Dutch local policies and the role of contextual factors. Local Environ 17(4):441-460

17. Biesbroek G, Swart R, Van der Knaap W (2009) The mitigation-adaptation dichotomy and the role of spatial planning. Habitat Int 33(3):230-237
18. Biesbroek G, Swart R, Carter T, Cowan C, Henrichs T, Mela H, Rey D (2010) Europe adapts to climate change: comparing national adaptation strategies. Global Environ Change 20(3):440-450

19. Tol R (2005) Adaptation and mitigation: trade-offs in substance and methods. Environ Sci Pol 8(6):572-578

20. Mees H, Driessen P, Runhaar H, Stamatelos J (2013) Who governs climate adaptation? Getting green roofs for stormwater retention off the ground. J Environ Plan Manag 56(6):802-825

21. Bulkeley H, Betsill M (2003) Cities and climate change: urban sustainability and global environmental governance. Routledge, New York

22. Bulkeley H, Betsill M (2005) Rethinking sustainable cities: multilevel governance and the 'urban' politics of climate change. Environ Politics 14(1):42-63

23. Betsill M, Bulkeley $H$ (2006) Cities and the multilevel governance of global climate change. Global Governance Rev Multilateralism Int Organ 12(2):141-159

24. Kern K, Bulkeley H (2009) Cities, Europeanization and multi-level governance: governing climate change through transnational municipal networks. JCMS J Common Market Stud 47(2):309-332

25. Bulkeley H (2013) Cities and climate change. Routledge, New York

26. Lafferty W, Coenen F (2001) Conclusions and perspectives. In: Lafferty W (ed) Sustainable communities in Europe. Earthscan, London, pp 266-304

27. Kern K, Koll C, Schophaus M (2004) Local Agenda 21 in Germany: an inter- and intranational comparison. Discussion paper. Wissenschaftszentrum Berlin für Sozialforschung, Berlin

28. Zahran S, Brody S, Vedlitz A, Grover H, Miller C (2008) Vulnerability and capacity: explaining local commitment to climate-change policy. Environ Planning C, Government Policy 26(3):544

29. Bulkeley H, Schroeder H, Janda K, Zhao J, Armstrong A, Chu S, Ghosh S (2009) Cities and climate change: the role of institutions, governance and urban planning. In: 5 th urban research symposium: cities and climate change, Marseille, 28-30 June 2009

30. Sharp E, Daley D, Lynch M (2011) Understanding local adoption and implementation of climate change mitigation policy. Urban Aff Rev 47(3):433-457

31. Yin R (2003) Case study research: design and methods, 3rd edition. Sage, Thousand Oaks

32. Van den Berg M (2013) Policy making on an uncertain climate: adaptation to climate change by local governments. Dissertation. University of Twente, Enschede, The Netherlands

33. Coenen F, Menkveld M (2003) The role of local authorities in a transition towards a climate neutral society. In: Kok M, Vermeulen W, Faaij A, De JD (ed) Global warming and social innovation: the challenge of a climate neutral society. Earthscan, London, pp 107-125

34. Hoppe $\mathrm{T}$ (2009) $\mathrm{CO}_{2}$ Reductie in de Bestaande Woningbouw: een Beleidswetenschappelijk Onderzoek Naar Ambitie en Realisatie. Dissertation. University of Twente, Enschede

35. Hoppe T, Van den Akker D, Kroeze K (2014) Lessen aanpak gemeente Lochem. CSTM Universiteit Twente/Oprit duurzaamheid, Enschede

36. Van de Graaf H, Hoppe R (1996) Beleid en politiek; een inleiding tot de beleidwetenschap en de beleidskunde, 3rd edition. Dick Coutinho, Bussum

37. De Jong J, Weeda E, Westerwoudt T, Correljé A (2005) Dertig jaar Nederlands energiebeleid. Clingendael, The Hague

38. Van der Doelen F, Klok P-J (1993) Beleidsinstrumenten. In: Hoogerwerf A (ed) Overheidsbeleid, 5th edition. Tjeenk Willink, Alphen aan den Rijn

39. Bressers J, Klok P (1987) Een voorlopige instrumententheorie van het milieubeleid. Ministerie van Volkshuisvesting, Ruimtelijke Ordening en Milieubeheer, The Hague

40. Bressers H, De Bruijn T, Lulofs K (2004) De evaluatie van de Nederlandse milieuconvenanten. Beleidswetenschap 3:242-270

41. Maarse JAM (1993) De uitvoering van overheidsbeleid. In: Hoogerwerf A (ed) Overheidsbeleid; een inleiding in de beleidswetenschap. Samsom H.D. Tjeenk Willink, Alphen aan den Rijn, pp 144-160

42. Knudsen JK (2009) Environmental policy integration and energy: conceptual clarification and comparative analysis of standards and mechanisms. Dissertation. University of Twente, Enschede

43. WCED (1987) Our common future. World Commission on Environment and Development. Oxford University Press, Oxford

44. VROM, Ministerie van (1998) Uitvoeringsnota klimaatbeleid. VROM, Ministerie van, The Hague 
45. Coenen F (1998) The Netherlands: subsidized seed in fertile soil. In: Lafferty WM, Eckerberg K (ed) From the Earth Summit to Local Agenda 21. Working towards sustainable development. Earthscan, London

46. Tweede Kamer der Staten Generaal (1999) Uitvoeringsnota klimaatbeleid Brief van de minister van Volkshuisvesting, Ruimtelijke Ordening en Milieubeheer. 26603 Nr. 2. Vergaderjaar 1998-1999. Tweede Kamer der Staten Generaal, The Hague

47. Harmsen T (2013) Nederlands klimaatbeleid ratjetoe. Openbaar Bestuur 23(7):17-18

48. Hoppe T (2013) Passie voor de klimaatopgave? beleidsrelevante wetenschap kritisch beschouwd. In: Trommel W, Van Genugten M, Honingh M (ed) Passie voor de publieke zaak. Boom Lemma uitgevers, Den Haag, pp 37-57

49. VROM, Ministerie van (1999) Bestuursakkoord Nieuwe Stijl. VROM, Ministerie van, The Hague

50. de la Court T (2003) De grenzeloos duurzame gemeente; verslag van de Lokale Duurzaamheidspiegel 2003. COS Noord-Holland, Alkmaar

51. Van Bueren E, Steenhuisen B (2013) Lokale energievisies als instrument. Bestuurswetenschappen 67(2):23-39

52. COS (2009) Lokale duurzaamheidsmeter. COS Nederland, Alkmaar

53. KplusV (2006) Tweede tussenevaluatie BANS-regeling en BANS-uitvoering. KplusV, Arnhem

54. VNG, Ministerie van Verkeer en Waterstaat, Minister van Economische Zaken, Minister van Wonen Wijken en Integratie, Minister van Ruimte en Milieu, Minister van Landbouw Natuur en Voedselkwaliteit, Staatssecretaris van Financiën, Staatssecretaris voor Europese Zaken (2007) Klimaatakkoord Gemeenten en rijk 2007-2011. Den Haag

55. Harmsen H, Lamers M (2013) Nederlands klimaatmitigatiebeleid top-down of bottom-up? Onderzoek naar de gemeentelijke sturingsrol binnen het klimaatmitigatiebeleid. Bestuurskunde 22(3):65-74

56. VROM, Ministerie van (2008) Stimuleringsregeling Lokale Klimaatinitiatieven. VROM, Ministerie van, The Hague

57. VROM, Ministerie van (2008) Nieuwe energie voor klimaat. VROM, Ministerie van, The Hague

58. Hoppe T, Sanders M (2012) Lokaal klimaatbeleid. Openbaar Bestuur 22(4):7-11

59. DHV (2010) Gemeenteakkoorden: Duurzaamheid vaker aan bod dan bezuinigingen. $\mathrm{DHV}$, Amersfoort

60. VNG, Royal HaskoningDHV (2013) Gemeentelijke Barometer Fysieke Leefomgeving. VNG, Royal HaskoningDHV, The Hague

61. KplusV (2012) Rapportage evaluatie Klimaatakkoorden; deel 2: Analyse en aanbevelingen voor de klimaatagenda. KplusV, Arnhem

62. Klimaatverbond (2011) Ledenenquête Klimaatverbond: grote gevolgen einde SLOK-regeling. In: http://www.klimaatverbond.nl/nieuws/ledenenqueteklimaatverbond-grote-gevolgen-einde-slok-regeling. Accessed 24 June 2013

63. Hoppe T (2012) Adoption of innovative energy systems in social housing: lessons from eight large-scale renovation projects in the Netherlands. Energy Policy 51:791-801

64. Messing M (2013) Burger waar bemoei je je mee? In: http://www. energieakkoordser.nl/nieuws/blogs/blog-burger-waar-bemoei-je-je-mee.aspx. Accessed 23 Feb 2013

65. Straatman E, Hoppe T, Sanders M (2013) Bestuurlijke ondersteuning van lokale energie-initiatieven; Duurzaam Dorp in Overijssel. ROMagazine 31(5):30-32

66. European Environment Agency (2006) Vulnerability and adaptation to climate change in Europe. European Environment Agency, Copenhagen

67. Terpstra T (2010) Flood preparedness: thoughts, feelings and intentions of the Dutch public. University of Twente, Enschede

68. Van den Berg M (2013) Transferring adaptation from the national to the local: exploring Dutch experiences. In: De Boer C, Vinke-De Kruijf J, Ozerol G, Bressers $\mathrm{H}$ (ed) Water governance, policy and knowledge transfer: international studies on contextual water management. Routledge, London, pp 207-223

69. VROM, Ministerie van (2007) Maak ruimte voor klimaat! Nationale adaptatiestrategie - de beleidsnotitie. VROM, Ministerie van, The Hague

70. Eerste Kamer (2005) Motie-Lemstra C.S. over langetermijninvesteringsstrategieën inzake grote nationale investeringen. Vergaderjaar 2004-2005, XXI-C. SDU, The Hague

71. Rekenkamer A (2012) Aanpassing aan klimaatverandering: strategie en beleid. Algemene Rekenkamer, The Hague
72. Van den Berg M, Lafferty W, Coenen F (2010) Adaptation to climate change induced flooding in Dutch municipalities. In: Martens P, Chang C (ed) The social and behavioural aspects of climate change: linking vulnerability, adaptation and mitigation. Greenleaf, Sheffield, pp 130-157

73. Runhaar H, Mees H, Wardekker A, Van der Sluijs J, Driessen P (2012) Adaptation to climate change-related risks in Dutch urban areas: stimuli and barriers. Reg Environ Change 12(4):777-790

74. Uittenbroek C, Janssen-Jansen L, Runhaar H (2013) Mainstreaming climate adaptation into urban planning: overcoming barriers, seizing opportunities and evaluating the results in two Dutch case studies. Reg Environ Change 13(2):399-411

75. Pötz H, Bleuzé P (2012) Groenblauwe netwerken voor duurzame en dynamische steden. Coop For Life, Delft

76. VNG (2007) VNG standpunt EU Groenboek: "Aanpassing aan klimaatverandering in Europa - mogelijkheden voor EU-actie.". Vereniging van Nederlandse gemeenten (VNG), The Hague, p 4

77. Mees H, Driessen P (2011) Adaptation to climate change in urban areas: climate-greening London, Rotterdam, and Toronto. Climate Law 2(2):251-280

78. Ministerie van Infrastructuur en Milieu (2013) Uitstelbrief Klimaatroadmap. Kenmerk IENM/BSK-2013/121457. Kamerstuk, The Hague. http://www. rijksoverheid.nl/documenten-en-publicaties/kamerstukken/2013/06/27/ uitstelbrief-klimaatroadmap.html. Accessed 21 Mar 2014

79. Rosenthal C, Shafer M (2013) Green cities: capacity, diffusion and implementation of sustainable policies. Paper presented at the national adaptation forum, Denver, 2 April 2013

doi:10.1186/2192-0567-4-8

Cite this article as: Hoppe et al:: Reflections on the uptake of climate change policies by local governments: facing the challenges of mitigation and adaptation. Energy, Sustainability and Society 2014 4:8.

\section{Submit your manuscript to a SpringerOpen ${ }^{\odot}$ journal and benefit from:}

- Convenient online submission

- Rigorous peer review

- Immediate publication on acceptance

- Open access: articles freely available online

- High visibility within the field

- Retaining the copyright to your article

Submit your next manuscript at $>$ springeropen.com 